\title{
Fostering Language and Vocabulary in International Business Students thorough an E Portfolio
}

DOI: $10.46932 / \mathrm{sfjdv} 2 \mathrm{n} 2-147$

Received in: March 1st, 2021

Accepted in: May 30th, 2021

\section{María Alexandra Rincón Pardo}

Who is certified in Foreign Languages Teacher (English and French) degreed at Universidad Pedagogica y Tecnológica de Colombia and who has earned a degree in a Master of Teaching English as a Foreign Language in Universidad Internacional Iberoamericana - UNINI Puerto Rico USA y Universidad Internacional Iberoamericana - UNINI México. And Specialist in Application of Digital Educational Recourses In Education. who is coursing a Master in in Application of Digital Educational Recourses In Education. Universidad de Cartagena Colombia . Furthermore, Research Teacher who has circulated research products on investigative journals and as speaker in International lectures represented Universidad Santo Tomas Tunja and UNAD . My teaching style combines different communicative approaches as well as methodologies through E-Learning with an experience of over 12 years now.

Current Institution

Universidad Santo Tomas de Tunja Colombia

Full address

Carrera 4 A N 7-47 Bochica, Tunja Boyacá Colombia

code postal 150001

E-mail: alexakorner@gmail.com

\begin{abstract}
This study analyzes the impact of the implementation of seven selected activities on E-portfolio in order to introduce international business students to the business vocabulary related to their program, given that they do not take any subjects related to their career in English. This study was carried out in a group of 20 students of second semester who study at a Universidad

Consequently, this study was conceived thanks some observations in classes of English that the lack of the use of Specific vocabulary in business which demonstrates language teachers follow a book to teach English and the text-book Speakout Eales, F., \& Oakes, S. (2011). Speakout: Elementary: Student's book. Pearson Education used in classes in order to support the contents of English is not focused on teaching business-related vocabulary. Therefore, there are no current opportunities for students to have contact with authentic language in Business subjects, in this case business vocabulary which could contribute to their professional growth. This confers to the idea to familiarize students with bussines-related vocabulary to the content area. The constructs which were considered in order to develop this research were firstly, the CALL (Computer-assisted language learning) approach taking advantage of E-portfolio, secondly, English for specific purposes (ESP) and finally Motivation. These theoretical constructs were considered thanks a diagnostic survey at the beginning of the first stage in this study.

The type of study was action research and qualitative methodology which lets teachers build theories related to teaching and learning; therefore, the data collection procedures included a teacher's journal with the purpose of recording ideas and reflecting on them afterwards, an online survey to reveal responses to specific, important questions, and e- portfolios which display evidence assembled and managed by students. Finally, the findings revealed three categories. First category is: Raising awareness about ESP. Second, Chasing a target vocabulary using E-portfolio that describes the outcome students achieved after developing different activities in a E-portfolio and how they learnt vocabulary confidentially and Third, Learning as a matter of motivation that relates to the interest students take for learning a language.
\end{abstract}


Finally, the conclusions describe students' prefers at the moment to use technology to foster their language learning and in order to increase their business lexis in English to face their profession in a meaningful way.

Key Words: E-portfolio, ESP, motivation, virtual tools.

\section{RESUMEN}

Este estudio analiza el impacto de la implementación de siete actividades seleccionadas en un E-portfolio para que los estudiantes internacionales de negocios aprendan vocabulario en Ingles relacionado con su programa, dado que no estudian ninguna materia relacionada con su carrera en inglés. Este estudio se llevó a cabo en un grupo de 20 estudiantes de segundo semestre de una Universidad.

En consecuencia, esta investigación se dio gracias a algunas observaciones en clases de inglés que demuestran que la falta de uso del vocabulario específico en la clase de negocios Internacionales demuestre que los profesores de inglés basan sus materia con el uso de un libro para enseñar inglés y el libro es utilizado para apoyar los contenidos de inglés y este no se enfoca en enseñar vocabulario relacionado con el negocio. Por lo tanto, no hay oportunidades para que los estudiantes tengan contacto con un el vocabulario técnico y auténtico en las materias de negocios Internacionales. En este caso, el vocabulario en inglés específico en negocios podría contribuir a su crecimiento profesional. Esto confiere la idea de familiarizar a los estudiantes con el vocabulario relacionado con el negocio en el área de su conocimiento. Los constructos teóricos que se consideraron para desarrollar esta investigación fueron, en primer lugar, el enfoque CALL (Aprendizaje de idiomas asistido por computadora) aprovechando el Eportfolio, en segundo lugar, el inglés para fines específicos (ESP) y finalmente la Motivación. Estos constructos teóricos se consideraron gracias a una encuesta de diagnóstico al comienzo de la primera etapa de este estudio.

El tipo de estudio fue la investigación de acción-participación y la metodología cualitativa que permite a los profesores construir teorías relacionadas con la enseñanza y el aprendizaje; por lo tanto, los procedimientos de recopilación de datos fueron un diario de campo del docente con el objetivo de registrar ideas y reflexionar sobre ellas posteriormente, una encuesta en línea tipo Likert para revelar respuestas a preguntas importantes e importantes y portafolios electrónicos que muestran pruebas reunidas y administradas por los estudiantes. Finalmente, los hallazgos revelaron tres categorías. La primera categoría es: Concienciar ESP. En segundo lugar, Aprendiendo vocabulario especifico utilizando Eportfolio que describe el resultado que los estudiantes lograron después de desarrollar diferentes actividades en un E-portfolio y cómo aprendieron el vocabulario de forma confidencial y la tercera categoría Es una cuestión de motivación, que se relaciona con el interés de los estudiantes en aprender un idioma. Finalmente, las conclusiones describen que los estudiantes prefieren en este momento usar la tecnología para fomentar su aprendizaje de idiomas y para aumentar su vocabulario de negocios en inglés para enfrentar su profesión de una manera significativa.

Palabras Claves: E-portafolio, ESP (ingles con propósito específico), motivación, herramientas virtuales.

\section{PROBLEM}

Santo Tomás University in Tunja knows the importance of learning English for academic, social and professional development in Tomasino students in the International Business academic program. Standards which are adopted by the university are pertinent with perspective of the government, according to MEN and Anne-Marie Truscott de Mejía of Centro de Investigación y Formación en Educación de la 
Universidad Andes, when states "Today Spanish is a language of international English, German and French among others. A Colombian student who achieves a good performance in his/ her native language and abilities in others, a bilingual student, he/she will be able to face new competences in his/her contact with the world". Moreover, our students have not taken any classes focused on specific language which help to their academic programs. For example, in reading academic articles given by their teacher of their specific subjects in their career. For that reason, they need a basis to be motivated learn a foreign language and using in their specific subtest.

\section{THEORETICAL REVIEW}

This research has been supported under the following theoretical constructors which have given a determinate chain of coherent concepts that are coincided with the constructions of the categories exposed in the result sections.

\subsection{CALL IN ENGLISH LEARNING. (COMPUTER ASSISTED LANGUAGE LEARNING)}

Over the past few decades, computer-assisted language learning (CALL) has become an important element of language learning which supports the idea that computers should be used as a medium to facilitate language learning. Levy defined computer-assisted as a base of learning and teaching consider it as the beginning of the investigation of the role of communication technologies around the learning of English. As Khan, B.H (2005) Butler-Pascoe and E. Ellen, 1997 Crystal, D 1997, Oliva, M. and Y. Pollastrini 1995 quoted by Mahmoudi, Samadb, Razakc ( 2012) (Mahmoudi, 2012) assert the new educational models have shifted from teacher-centered to learner-centered classrooms by way of welldesigned. Also, using multimedia technology in teaching English as a foreign language can help the learners increase their independence and solve some of the difficulties experienced in a traditional classroom.

According to e (Hanson-Smith, 1997) Jaber (1997) quoted by Başöz \& Çubukçu (2014)

The use of CALL and web-based environments are appropriate to the alternative methodologies of modern foreign-language instruction. Use of a variety of educational technologies both improves the quality of education and strengthens learning environment in a way to enable students to learn a foreign language effectively and flexible environments. (p. 5)

Consequently, the teachers are responsible at using the technology in order to foster language skills thanks the use of virtual tools have given the opportunity to be flexibility and accessible to learners' needs and interests. Also, In another study (Önsoy, 2004; Tang (1995); Min (1998) that focused on the attitudes of students and teachers towards the use of CALL, both students' and teachers' attitudes towards CALL 
were found to be positive.This points that both have been motivated at using of computers in learning English as a foreign language. and CALL Pegrum (2009) Yüksel \& Kavanoz (2010) proposed by Gardner (1998) have been driving an initiative in new trendies about English learning and connectivism method as approach to multiple intelligences and competences.

\subsection{E-PORTFOLIO}

According to Goldsmith, D. J. (2007), Alverno College (2006), Gray, L. (2008).E-portfolios are a rich, flexible tool for teaching, learning, and assessment. They provide institutions with a way to assess how well they are educating their students. Furthermore, E-portfolios have supplied relevant tools in higher education in order to do assessment in different knowledge areas. All portfolios, paper based or electronic, generally share three basic characteristics that allow them to be used as an assessment tool according to Goldsmith, D. J. (2007).

(1)The ability to collect materials created for a variety of reasons over time, (2) the ability to select from this collection and organize it, and (3) the ability to surround the work itself with additional information and content, including introductions and reflection. (p. 6)

Furthermore, Gray, L. (2008) desserts that the Effective practice with e-Portfolios in-class and outclass has supported the effective learning in a foreign language and e-Portfolio-based learning explore in more depth the circumstances in which e-portfolio development can:

- Improve understanding of the self and the curriculum

- Engage and motivate learners, both individually and as part of a community of practice

- Personalize learning

- Support models of learning appropriate to a digital age

- Promote reflective practice

Hanson, J. and Uddin, A. (2007) asserts "Reflective e-portfolios are the 'critical thinking space' in which learners address what is important to them as individuals, including how they learn and what their chosen academic and career pathways demand of them." (p. 35). At the same road Beetham, H. (2007) states "e-Portfolios can mean different things in different contexts. Establish the purpose and objectives of your e-portfolio initiative. Define the issues it aims to address, the likely support needs of the learners and the nature of the learning environment" (p.37). Consequently, e-portfolio have been a natural tool which transform learning aims in a friendly learning environment where the learners should select their objective of learning and goals. Hallam, Gillian C., Harper, Wendy E., McCowan, Colin R., Hauville, Kim L., McAllister, Lynn M., \& Creagh, Tracy A. (2008) Affirm that "The greatest use of ePortfolios was recorded in coursework programs, rather than in research programs, with implementation 
generally reflecting subject-specific or program-based activity, as opposed to faculty- or university-wide activity. "This means that higher education must contribute ICT services in careers and employment or teaching and learning support in order to emerge technology strategies and digital competences in teachers and students, too.

Lorenzo, G., \& Ittelson, J. (2005) assert that the attitude and emotions at using the e-portfolio give and friendly environment with teaches' feedback about the e-portfolio. "a positive attitude towards the promotion of self-assessment and peer assessment through the use of the e-portfolio. Furthermore, the learners showed great interest for the e-portfolio tool and reacted positively in using it". (p.4) Consequently, the e-portfolio is proved to be successfully implemented in classroom, and its application revealed in the classmates helped the students to develop the process of self-assessment at a high level or higher education.

\subsection{ESP (ENGLISH SPECIFIC PROPOSES)}

ESP has been a variation of method which is fomented in order to teach specific English around an academic programs of specific brunches of humanities and sciences, Ahmad Y. (2010) affirms "English for specific purposes (ESP) refers to the teaching and learning of English as a second or foreign language where the goal of the learners is to use English in a particular domain." (p.1). learners can dominate academic terms and feel or confidence in English learning as well. Moreover, the learners can be involved in meaningful environment where the motivation plays an important role in English learning. However, as Hutchinson and A. Waters (1987) affirms quoted by Ahmad Y. (2010) "ESP is not just a matter of Science words and grammar for Scientists, Hotel words and grammar for Hotel staff and so on." Because this could be taught in order to catch a language is involved in target situation which student needs.

According to Hutchinson and Waters ELT Tree illustrate the way how a student can learn English in different fields or spaces of their profession and academic life. For example, if a student needs to get a specific exam to get a job, he probably needs to learn specific vocabulary to get it or if a student of an academic program requests to read a scientific article, he/ she should learn new vocabulary focused on a specific academic brunch. 
Figure 1 Figure 1: ELT Tree (Hutchinson and Waters 1987, p. 17)

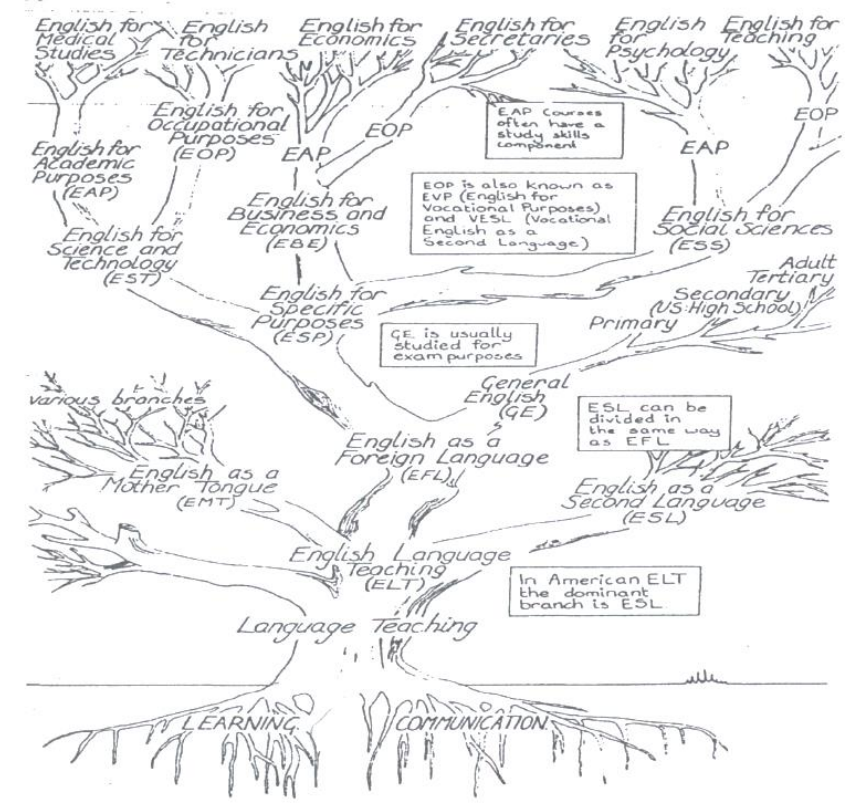

Dudley-Evans (2001) briefly explained Robinson's view of "ESP as a goal-directed approach that has a limited time period and is aimed at adults in homogeneous learning environments"(p.384). Also, Dudley-Evans (2001) also included three variables: ESP has to be related to specific disciplines, use a different methodology from the one used in General English, and be aimed at intermediate to advanced adult learners (p. 131). Adults and university student are emerged in academic environments which request them to use specific terms and vocabulary in English. Consequently, they need empower their English learning abilities in general English but reinforce specific English with academic proposes as well. This is drawn is all academic fields.

Globalization directly influences industry's needs; a global engineer must be able to easily cross national and cultural boundaries. This in turn directly affects engineering education. A common code for communication is required. Those education institutions, which meet the language requirements for the new global engineer, will be ready to face the new millennium. Riemer, M.J. (2002, p. 91).

Pérez-Sabater, C. and Montero-Fleta, B. (2015). ESP vocabulary and social networking is other environment which the students have explored in order to learn English and specific areas of knowledge which are used on social networks such as Facebook, tweeter, among others. For that reason, Sabater affirms "ESP students have very particular linguistic needs in their communities of practice, their discourses and the types of documentation they use"(para. 7).

\subsection{MOTIVATION IN ENGLISH LEARNING (INTEGRATIVE \& INSTRUMENTAL MOTIVATION).}

A concept of both motivations are drawn by R. C. Gardner (2008) "Integrative motivation was 
Integrative reasons are defined as those, which indicate an interest in learning the language in order to meet and communicate with members of the second language community. Instrumental reasons refer to those reasons, which stress the pragmatic aspects of learning the second language, without and particular interest in communicating with the second language community (Samada, Etemadzadehb \& Farc 2012, par.7).

Zhenga, Liangbd, Lic and Tsaibd (2012) confirm 'Ideal L2 Self' includes factors such as attaining high proficiency in English to achieve a better future self (instrumentality of promotion), to appreciate cultural products in English (cultural interest), or to travel in English-speaking countries (traveling). On the contrary, their 'Ought-to L2 Self' indicates various duties or responsibilities, such as minimizing negative academic performance (instrumentality of prevention) and fulfilling their social obligations (parental expectations).

Intrinsic Motivation. Intrinsic motivation can be associated with the inner feelings of learners and it considers how learners engage in the task, and if they are willing to be involved in the activity. The rewards do not relate to external factors. Deci and Ryan (1980) suggest that learners who are intrinsically motivated learn well and are high achievers.

According to Özgür \& Griffiths (2013) has typically been divided into four types:

Extrinsic Motivation. Extrinsic motivation is driven by desire for reward from outside: parents, employers, teachers or others. Extrinsic motivation may also have a negative purpose to avoid punishment, ridicule or loss of status (Ryan and Deci, 2000) quoted by Özgür \& Griffiths (2013)

Integrative Motivation. According to Gardner (2001), integrative motivation plays a major role in successful language learning. When the learner's attitudes towards L2 are positive, they easily become a part of L2 culture (Gardner and Lambert, 1959, 1972).

Instrumental Motivation. Instrumental motivation is related to learners' practical needs, such as to find a good job, or to have a high income (Gardner and Lambert, 1959, 1972). Whereas intrinsically motivated learners want to achieve a goal for their own satisfaction, instrumental motivation is used as a tool in order to achieve something else.

\section{METHODOLOGY}

The type of study conducted was action research. Accordingly, the research instruments were a survey type Likert was answered by 20 students which aims at knowing in different scales likes and dislikes or learners' perceptions about the use of virtual tools in English learning. At the same time, a field 
diary written by teacher (teacher's journal) to know students' attitudes perceived through observations taking into accounting Behaviorist approach. Additionally, learner's comments and perceptions were determinate about the activities developed in class on E-portfolio, an online survey which was answered by 20 students of International Business academic program in order to gather information about the tasks implemented to foster language and vocabulary which contribute to get more relevant information and students' artifacts that were collected by using the platform Wix, in this case a E-portfolio which shows what students created. Given that, a triangulation of information is considered in order to establish three categories.

Apart from this data collection, it is considered a methodology process using the E-portfolio which was designed by themselves taking into accounting the creation of 4 taps (these are the different access buttons on a website which can bring to more information to the users). These are: Home, glossary, what I looked for, what I learnt and Feedback. For instance, on Home tap, the learners could register their personal information, profile, pictures, likes and dislikes, free time, hobbies, expectations about their English learning process and contact data where they could use Facebook and tweeter. On Glossary tap, the main vocabulary was stored and used during each topic study and each task done. About What I looked for is one of main tap which aims at searching relevant information about the proposed topic by the teacher. In this case, the teacher has proposed 5 topics which were: First, Successful business man; second, A recognized multinational and its history; third, a profitable invention of the history; fourth, the language of agreement and advice across cultures and last one, manners and tips in a job interview.

Furthermore, What I learnt is other activity tap which points at making and designing online or virtual activities that show how the learners have created themselves online material in order to evince their learning autonomous process. For Instance, a topic as Successful Business man was considered on an online reading, then the students had to select an activity or exercises bringing to a virtual tool and this evinces what they have learnt from this reading selected.

These activities on E-portfolio are composed by tasks. The first task refers to create a Wix with their preferred design and favorite templates that this virtual tool offers. Secondly, a profile was written about their personal information. Thirdly, some relevant topics are selected by the teacher considering the Syllabus of second semester in International Business academic program such as: Successful business man; second, A recognized multinational and its history, a profitable invention of the history The language of agreement and advice across cultures and manners and tips in a job interviewin order to be researched and read . Fourthly, information about topics were searched and selected by them on internet. Then, a virtual activity or tool is designed by themselves in order to validate that they have learnt and have had an autonomous and meaningful learning process. Then, a tutorial guide is given by the teacher which 
helps students at improving their autonomous learning strategy. Finally, a oral presentation using the Wix in front of the class is done by the learners who tell about their perceptions, experiences, thoughts and feeling during their learning performance.

\section{RESULTS}

The findings in data collection displayed three categories: Category 1: Raising awareness about ESP, category 2: Chasing a target vocabulary using E-portfolio and category 3 Learning as a matter of motivation. These were considered thanks to the coincidences among the learners' answers which were picked up from the three data instruments and a triangulation has been applied as method of analysis and taking into the support of the theoretical framework studied as a referent as well as.

The following figures show the behavior of some answers to 5 questions that are part of a survey type Likert, the 5 questions of questionnaire answers analyzed at the end of the investigative process and some excerpts from teacher's dairy. These were taken since the beginning till the end of this study. Moreover, these collaborated to construct the categories which are displayed during the discussion. Also, the instrument were answered individually by 20 level-A1 English students of second semester of International Business at Santo Tomás University Tunja, Colombia. The results are shown below:

Figure 1 Results of Survey, Question \# 1What Importance average do you give at learning English for International Business program.

\section{Importance at learning Basic English Vocabulary} for International Business

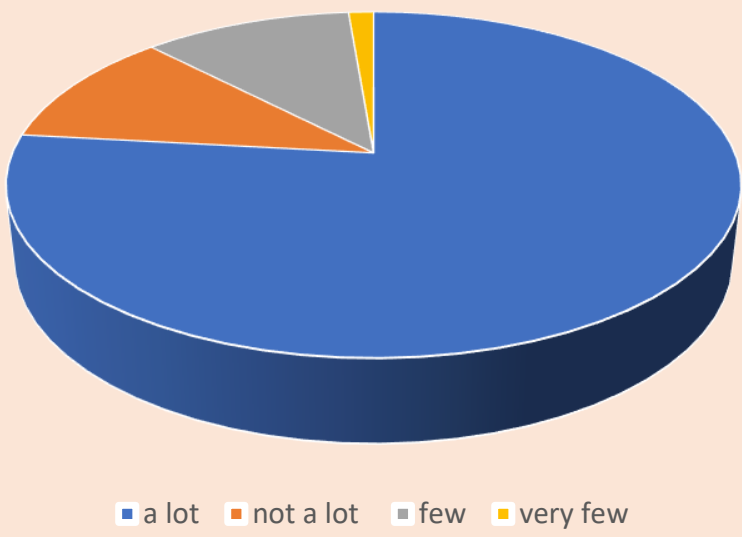

From the previous figure, it can see the participant's perceptions around the importance at learning Specific English with particular propose which aims to gain more Business vocabulary in the subject Introduction to International Business. $80 \%$ of participant state the importance of learning Business vocabulary is evident in order to increase satisfactory results during their academic programs. 
Figure 2 Results of Questionnaire, Question \# 1what appreciation do you give at using virtual tools during Basic English vocabulary learning in International Business.

\section{Motivation at using virtual tools during Basic \\ english vocabulary Learning in \\ International Business}

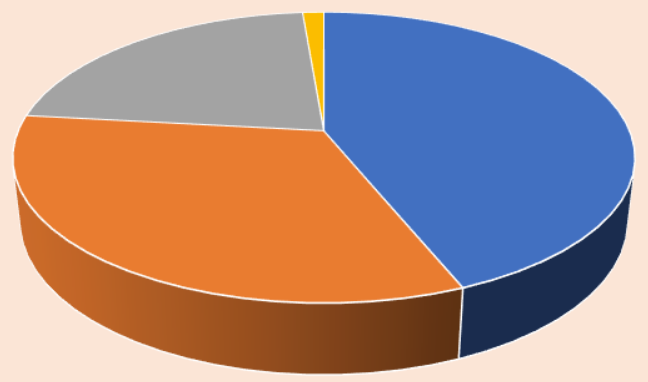

- motivated " innovated $=$ useful - difficult

Based on this question, in the previous figure it is clear that for the $40 \%$ of students surveyed agreed that the use of technology tools and virtual instruments are pertinent as a motivated fact during their learning process. The rest of $40 \%$ conceived that the virtual tools are innovated in order to gain more English vocabulary which enrich the International Business subject. This demonstrates one more time the positive impact that the involvement of virtual tools. However, a minimum of students consider difficult to use virtual media in order to learn.

Figure 3 Results of Questionnaire, Question \# 2 Do you consider Motivated and meaningful learning through E-portfolio?

\section{Motivation and Meaningful Learning Throught the Designing of an E-portfolio.}

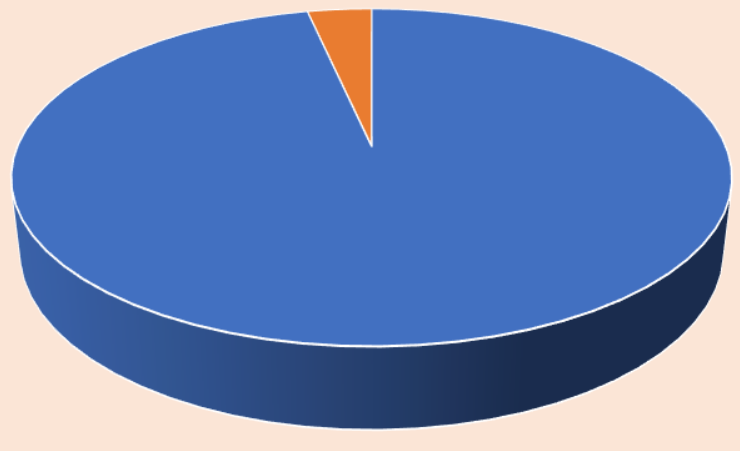

- Yes - No

Considering the previous sample, the members of the group validate that the online resource used facilitated learning of basic vocabulary in International Business and therefore this tool is motivating for 
their Meaningful learning by some $90 \%$.However, $10 \%$ find some difficulties around the use of technology and management of independent time in order to make the activities in an autonomous way.

\subsection{TEACHER'S DAIRY}

Taking into account the teacher's observations and excerpts obtained class by class and tutorial activity with the feedback exercises during 5 months with a mount of 2 hours per week, the following results are provided.

- The students are satisfied with the use of a Virtual tools taking into account a basic knowledge of them. The most of students agreed with the use of an E-portfolio considering the importance of implementing Business vocabulary of their academic program, because they use it during the development of their classes.

- The students show liking when some selected online activities chosen by themselves such as: videos, scrambles, crosswords, mind maps among others could help them in order to be more innovate their autonomous learning, given that they were who created this online material.

- The learners expressed the evident pertinence at learning specific English with the propose of enriching English vocabulary point their academic program. Thus, they showed in their speech that to be awareness about use this language in their classes help to obtain power during the academic reading.

- The access is effective at using Internet, tablets, laptops, desktops at laboratory. For that reason, the range permits learners can work and access to websites. However, some of them have noticed that independent work at home is more comfortable at the moment to access to Wix.

\subsection{DISCUSSION}

In this stage of the research three categories were took into account according to the instruments collection (survey, teacher's journal and students' E-portfolio) and retaking theoretical framework which was a support to give argument to this research. As Morse and Richards cite (2002), "a concept is a mental image that is a higher level abstract construct than a category. A category is simply putting together abstracted elements of data into a like-set (group)" (pag.149). Each word, phrase, expressions and the repetitions of opinions are elemental during the data analysis writing, the need for further refinement of categorization or conceptualization may become evident or further interpretive insight may emerge. Writing may provide additional clarity until meaning is (or seems) complete or 'saturated' (Giddings, 2007, p.149).

Also, this stage explains the importance of learning vocabulary to becoming proficient business language , after applying seventh tasks activities on a E-portfolio such as: designing of a E-portfolio with 
a Wix, creation of a Students' profile, search of the main topics on internet about International Business given by the teacher, designing of virtual activities in order to learn specific vocabulary, tutorial guide with the teacher on E-portfolio and online material, feedback about the activities and tasks and finally presentations of each E-portfolio to classmates.

Consequently, the learners were awareness about the importance of learning specific vocabulary in Business about their subject named "Introduction to International Business" which offers a selective glossary in English and this is reinforced in English class with the help of a virtual tool. At the same time, the meaningful learning stayed afloat considering that the learners applied their basic business vocabulary into their English class and they felt more confidence in Business subject when they faced new challenges using basic information in English with his/her teacher in Introduction business class.

\section{RAISING AWARENESS ABOUT ESP}

Which analyzes that although students knew the importance of learning Specific English for growing their English learning, they have not study before. Concerning this drawback, every single question student got was just an expression of interest and empowerment to foster their motivation and learning. Although students had to follow certain tasks on their E-portfolio to create their activities themselves, another process became important at the same time, it was to present them in front of their classmates and a co-evaluation was done by them, after to be awarded of their process considering a selfassessment.

Moreover, this dealt with the importance that students gave to the comments provided by their teacher and the role of the contributions played in students' survey and teacher's journal. Moreover, it shows the evidence through the importance to learn a foreign language thanks a variety of class as is ESP which states a relevant importance in their meaningful learning during the development of their using virtual tools. Also, this category describes how students enrich their vocabulary throughout the development of the different tasks set by the tutor and illustrates how language becomes important to convey meaning specifically when talking about business.

Dudley-Evans, T. (2001). And Riemer (2002), quoted by Ahmad Yasruddin M (2010) declare "the concept of English for Special Purposes (ESP), will achieve more in the education of engineering students by focusing on the learner's attention on the particular terminology and communication skills required in the workplace" (para.5).

St 10 said: "10 Me pareció interesante, por este medio podemos adquirir conocimientos que a futuro nos servirán en nuestra vida profesional"(FG-10- Q).

This student confirmed that international business students need and introduction in English about 
basic topics of their profession at least to have a background of business language in a world which demands competences and abilities in professions as engineering and other labor fields.

"The successful incorporation of technologies in education basically depends on a clear understanding of the technology and on the achievement of a set of well-defined objectives based on a sound learning approach" (Zhao, 1996 quoted by Pérez-Sabater and Montero-Fleta. 2015, p. 130), this student maintained that virtual tools incorporation helps to be more successful in his/her English learning.

These category realties the importance to introduce a specific language takes students feel motivated. Although students knew the importance of learning Specific English for growing their English learning, they did not understand why they have not acquired before. Concerning this drawback, every single question students got was just an expression of interest and empowerment to foster their motivation and learning. Although students had to follow certain tasks to create their activities themselves, another process became important at the same time it was to present them and be awarded of their process.

\section{CHASING A TARGET VOCABULARY USING E-PORTFOLIO.}

Which explains that although students knew the importance of learning Specific English for increasing their English learning, they did not understand why they have not acquired before. Concerning this drawback, every single question students got was just an expression of interest and empowerment to foster their motivation and learning. Although, the students had to follow certain tasks to create their activities themselves, another process became important at the same time it was to present them and be awarded of their process.

According to Lorenzo and Ittelson (2005), e-portfolios are the personal and digital collection of artifacts of an individual including 'demonstrations, resources, and accomplishments' (p.2) for a variety of contexts and time periods. They have also mentioned that e-portfolios digitize students' works and can use the Internet to store them. In addition, Gray (2008) has stressed that an e-portfolio is "the product, created by the learner, a collection of digital artifacts articulating experiences, achievements and learning" (p.6). Gray has also stated that it is "a purposeful aggregation of digital items - ideas, evidence, reflections, feedback, etc., which presents a selected audience with evidence of a person's learning and/or ability" (p.7). Different definitions of e-portfolios indicate that they are student-centred. They also store students' individual works digitally and help follow students' learning process in different contexts and time periods.

The use of virtual tools on a wix as an E-portfolio for learning of vocabulary and the acquisition of vocabulary ESP in basic level as a support in Introduction of international business subject. Also, this category shows how business vocabulary in English helps to enrich basic lexis of subject studied in their 
academic program and think in its importance during their professional life and the third category found was “. I decided to call this category in this way because through the analysis I could evidence that there were factors that difficulted and facilitated the work with mobile devices. The next table shows the relationship among the subcategories, categories and the research questions.

\subsection{BENEFITS OF E-PORTFOLIOS}

E-portfolios are commonly used tools in different areas of education. This commonness has resulted in many studies on its use and its effects. These studies have revealed some benefits of eportfolios. One of the benefits is having an online virtual environment. Students share their "goals, achievements, and insights with advisors and counsellors" (Goldsmith, 2007, p.31) in this environment. Meanwhile, this gives them a chance to check whether they have met their educational and career goals. It can also indicate their achievements and skills through their e-portfolios to get a job. In other words, eportfolios are effective tools to improve students' marketability, career planning and development since they include learners' achievements, learning experiences, and skills.

According to learner's virtual tools are essential nowadays considering the importance of technology in English learning because each day new apps and Webpages are offered to the users.

St 8 said: "Me parece muy bueno el uso de un Wix para escoger nuestras propias actividades y aprender más del inglés para negocios.” (FG-8-SL).

\subsection{LEARNING AS A MATTER OF MOTIVATION}

Student's motivation was taken into accounting according to each expression of interest and incentive at the moment to use a virtual tool in their language learning process. Given that, they prefer a virtual environmental as an autonomous way to learn a language. For that reason, in this study was present two kinds of motivation: instrumental and integrative motivation. According to Gardner (1998) defined motivation as "the extent to which the individual works or strives to learn the language because of a desire to do so and the satisfaction experienced in this activity". This definition includes 1) effort expended to achieve a goal; 2) a desire to learn the language; and 3) satisfaction with the task of learning the language.

Studying the principal motives that prompted learners, laid particular stress on a distinction
between an integrative orientation and an instrumental orientation. Integrative motivation is
defined is a positive attitude towards the target language group and the potential for integrating
into that group. And instrumental motivation refers more functional reasons for learning a
language: to get a better job or promotion, or to pass required examination (Gardner, 1998, par.6.).

It is shown how students are motivated to work better in the sense of using virtual tools, creation of their own E-portfolio if they are monitored by a feedback that shows them what can do and how can 
do it in order to be motivated.

The Integrative \& instrumental motivation has been described in this study, because the students affirm that two motivations are moved in order to learn specific English. First, the motivation at getting a better job aboard and to obtain better applications to study in a foreign country. Al the same time, the motivation to be involved in a foreign culture which give a value to their professional performance in their academic program as International Business.

\section{CONCLUSION}

Based on the results of this study, on the one hand it was found that students had a specific purpose for studying English using ESP as a simple approach for vocabulary acquisition which would help them in their professional life. On the other hand, the use of Virtual tools as E-portfolio can be defined as an approaches to pedagogy or teaching, e.g. self-paced, collaborative, tutor-supported learning or traditional classroom teaching, since it helped students to enrich their reading skills when it came to tackling an academic article during International Business subjects.

As a result, they could use virtual tools as a strategy to enhance their autonomous learning and to be more confident when facing new challenges to learn a specific language. Moreover, E-portfolio is reaffirmed as a Virtual tool which reinforce language skills, collaborative work, autonomous learning and digital competences in students and teachers. Besides, as is the case for tutor-supported learning or traditional classroom teaching, at using E-portfolio can help the students need a guide in the classroom and need to be monitored or motivated according to their learning styles.

For that reason, the teachers must be responsible for motivating learners in class from the very first warm-up activity and go through the different stages of the class. But, over all the teachers must consider to motivate their students at using virtual tools in order to give more confidence during learning process.

The major goal of the project was to foster language and vocabulary that will support International Business students in learning English language in Santo Tomas University through the use of Virtual portfolio Wix. Another objective was to know the student's perceptions.

The motivation is one of the most important and relevant.

Taking into account the aforementioned analysis carried out after implementation of an E-portfolio in ESP Vocabulary learning and learners' motivation, it can be concluded that the students learned:

- The majority of students learn a foreign Language-English- thanks at using virtual tools which provide technology interest, audio-lingual resources online and they can be closed a native environment with the use of Social nets. 
- The most of learners use E-portfolio as a creative and meaningful tool which is created by themselves in proportion of learning a foreign language.

- The majority of them concern that ESP is necessary into curricula as a way of implementing English learning in a meaningful way in order to learn, because the incorporation of Subjects in English help to enrich the language competences in the future professionals.

- The implementation of E-portfolio helps to motivate the creation of own material which will contribute new learning strategies in English learning. Given that, the students can discern what the most appropriate material is according to learn a topic or learners' academic needs. This process is guided by the teacher.

- Teachers are responsible about the learners' motivation in order to learn a foreign language. In this case, teachers must implement virtual tools during the teaching process because it favors their learner's motivation Integrative \& instrumental motivation as well. Given that, they can take advantage of technology and several website which are available in order to improve learning styles. Moreover, if we want to foster the motivation in our students about English learning, our students really need a starting use E-portfolio (virtual tool) how to build new knowledge.

- The feedback and monitoring were the touch that shaped the way as students organized their designing of E-portfolio and what they used to deal with it. 


\section{REFERENCES}

Ahmad Y. (2010). The English Proficiency of Civil Engineering Students at a Malaysian Polytechnic Department of Mathematics. Asian Social Science 6 (6), 161-170.

Beetham, H. (2007) Evaluating the learner experience: Some guidelines for e-learning projects, www.jisc.ac.uk/learnereval

Başöz \& Çubukçu Pre-service EFL teachers' attitudes towards Computer Assisted Language Learning (CALL) Procedia - Social and Behavioral Sciences Volume 116, 21 February 2014, Pages 531-535

Dudley-Evans, T. (2001). English for specific purposes. In R. Carter \& D. Nunan (Eds.). Teaching English to speakers of other languages (131-136). Cambridge: Cambridge University Press.

Eales, F., \& Oakes, S. (2011). Speakout: Elementary: Student's book. Pearson Education.

Gardner, R., \& MacIntyre, P. (1991). An Instrumental Motivation In Language Study: Who Says It Isn't Effective? Studies in Second Language Acquisition, 13(1), 57-72. doi:10.1017/S0272263100009724

Goldsmith, D. J. (2007). Enhancing learning and assessment through e-portfolios: A collaborative effort in Connecticut. New Directions for Student Services, 119, 31-42. doi: 10.1002/ss.247.

Gray, L. (2008). Effective practice with e-Portfolios. JISC, 5-40

Hallam, Gillian C., Harper, Wendy E., McCowan, Colin R., Hauville, Kim L., McAllister, Lynn M., \& Creagh, Tracy A. (2008) ePortfolio use by university students in Australia: Informing excellence in policy and practice. Australian ePortfolio Project, Stage 1. Queensland University of Technology, Department of Teaching and Learning Support Services, Brisbane, Qld.

Hanson, J. and Uddin, A. (2007) E-portfolios: employability or engagement? www.bournemouth.ac.uk/asprojects/pdp4x12/documents/SEECPresentation.pptpz

Levy, M., Computer-Assisted Language Learning, in Oxford University Press. 1997, New York.

Lorenzo, G., \& Ittelson, J. (2005). An overview of e-portfolios. Educause Learning Initiative, 1-27.

Mahmoudi, Samadb, Razakc. (2012). Attitude and Students' Performance in Computer Assisted English Language Learning (CAELL) for Learning Vocabulary Procedia - Social and Behavioral Sciences. Volume 66, 7 December 2012, Pages 489-498.

Ministerio de Educación Nacional. (2009). Bilingüismo en la educación superior. From https://www.mineducacion.gov.co/1621/article-196474.html

Morse J. (2011) Molding qualitative health research. Qualitative Health Research 21:1019-21

Morse J, Richards L. (2002). Read me first for a user's guide to qualitative methods. Sage, Thousand Oaks, California, USA

Özgür \& Griffiths (2013). Second Language Motivation. Procedia - Social and Behavioral Sciences.Volume 70, 25 January 2013, Pages 1109-1114. 
Riemer, M.J. (2002). English and Communication Skills for the Global Engineer. Global Journal of Engineering Education, Vol. 6, No. 1.

Pérez-Sabater, C. and Montero-Fleta, B. (2015). ESP vocabulary and social networking. The case of Twitter. Ibérica. (29), 129-154.

Samada, Etemadzadehb \& Farc (2012) Motivation and Language Proficiency: Instrumental and Integrative Aspects. Procedia - Social and Behavioral Sciences Volume 66, 7 December 2012, Pages 432440 open access

The Higher Education Academy, Getting started with e-portfolios: case studies www.ukcle.ac.uk/resources/ict/westminster.html 32

Zhenga, Liangbd, Lic and Tsaibd (2012). The relationship between English language learners' motivation and online self-regulation: A structural equation modelling approach. System

Volume 76, August 2018, Pages 144-157. 